\title{
Groundwater and porewater as major sources of alkalinity to a fringing coral reef lagoon (Muri Lagoon, Cook Islands)
}

\author{
T. Cyronak, I. R. Santos, D. V. Erler, and B. D. Eyre \\ Centre for Coastal Biogeochemistry, School of Environment, Science and Engineering, Southern Cross University, \\ Lismore, New South Wales, Australia
}

Correspondence to: T. Cyronak (tcyronak@gmail.com)

Received: 23 October 2012 - Published in Biogeosciences Discuss.: 5 November 2012

Revised: 22 March 2013 - Accepted: 22 March 2013 - Published: 15 April 2013

\begin{abstract}
To better predict how ocean acidification will affect coral reefs, it is important to understand how biogeochemical cycles on reefs alter carbonate chemistry over various temporal and spatial scales. This study quantifies the contribution of shallow porewater exchange (as quantified from advective chamber incubations) and fresh groundwater discharge (as traced by ${ }^{222} \mathrm{Rn}$ ) to total alkalinity (TA) dynamics on a fringing coral reef lagoon along the southern Pacific island of Rarotonga over a tidal and diel cycle. Benthic alkalinity fluxes were affected by the advective circulation of water through permeable sediments, with net daily flux rates of carbonate alkalinity ranging from -1.55 to $7.76 \mathrm{mmol} \mathrm{m}^{-2} \mathrm{~d}^{-1}$, depending on the advection rate. Submarine groundwater discharge (SGD) was a source of TA to the lagoon, with the highest flux rates measured at low tide, and an average daily TA flux of $1080 \mathrm{mmol} \mathrm{m}^{-2} \mathrm{~d}^{-1}$ at the sampling site. Both sources of TA were important on a reef-wide basis, although SGD acted solely as a delivery mechanism of TA to the lagoon, while porewater advection was either a sink or source of TA dependent on the time of day. This study describes overlooked sources of TA to coral reef ecosystems that can potentially alter water column carbonate chemistry. We suggest that porewater and groundwater fluxes of TA should be taken into account in ocean acidification models in order to properly address changing carbonate chemistry within coral reef ecosystems.
\end{abstract}

\section{Introduction}

The recent increase in atmospheric $\mathrm{CO}_{2}$ has led to an increase in oceanic $p \mathrm{CO}_{2}$ as roughly $30 \%$ of anthropogenic $\mathrm{CO}_{2}$ has been absorbed by the oceans (Feely et al., 2004; Sabine et al., 2004; Orr et al., 2005; Doney et al., 2009). Ocean acidification is the term given to this increase in oceanic $p \mathrm{CO}_{2}$, which alters the carbonate chemistry of seawater leading to a reduction in $\mathrm{pH}$ at a rate of roughly $0.002 \mathrm{pH} \mathrm{yr}^{-1}$ (Feely et al., 2004; Doney et al., 2009). Ocean acidification can have drastic effects on biological processes and the biogeochemistry of marine ecosystems, with coral reefs being some of the most susceptible ecosystems (Fabry et al., 2008; De'ath et al., 2009). The biogeochemical processes occurring in coral reefs can modify the carbonate chemistry of the overlying seawater, leading to large diel variations in alkalinity, $p \mathrm{CO}_{2}, \mathrm{pH}$, and dissolved oxygen (DO) (Santos et al., 2011; Shamberger et al., 2011; Gray et al., 2012; Shaw et al., 2012). In order to understand how ocean acidification will affect coral reefs, it is important to understand how natural processes, which can potentially buffer or intensify changes in seawater $\mathrm{pH}$, alter the carbonate chemistry of seawater within coral reef ecosystems.

As $\mathrm{CO}_{2}$ dissolves in water, it is hydrolyzed to form carbonic acid in the following equilibrium reactions:

$$
\mathrm{CO}_{2}+\mathrm{H}_{2} \mathrm{O} \leftrightarrow \mathrm{H}_{2} \mathrm{CO}_{3} \leftrightarrow \mathrm{H}^{+}+\mathrm{HCO}_{3}^{-} \leftrightarrow \mathrm{H}^{+}+\mathrm{CO}_{3}^{2-} .
$$

Due to the production of $\mathrm{HCO}_{3}^{-}$and $\mathrm{CO}_{3}^{2-}$, the increase in $\mathrm{H}^{+}$ions causes a reduction in seawater $\mathrm{pH}$ but does not change the total alkalinity (TA) (Millero, 1979; Zeebe and Wolf-Gladrow, 2001). The TA of a solution represents the ability of the solution to absorb $\mathrm{H}^{+}$ions without an 
associated reduction in the $\mathrm{pH}$, and in seawater is equal to the following equation (Wolf-Gladrow et al., 2007):

$$
\begin{aligned}
\mathrm{TA} & =\left[\mathrm{HCO}_{3}^{-}\right]+2\left[\mathrm{CO}_{3}^{2-}\right]+\left[\mathrm{B}(\mathrm{OH})_{4}^{-}\right]+\left[\mathrm{OH}^{-}\right] \\
& +\left[\mathrm{HPO}_{4}^{2-}\right]+2\left[\mathrm{PO}_{4}^{3-}\right]+\left[\mathrm{H}_{3} \mathrm{SiO}_{4}^{-}\right]+\left[\mathrm{NH}_{3}\right] \\
& +\left[\mathrm{HS}^{-}\right]-\left[\mathrm{H}^{+}\right]-\left[\mathrm{HSO}_{4}^{-}\right]-[\mathrm{HF}] \\
& -\left[\mathrm{H}_{3} \mathrm{PO}_{4}\right]-\left[\mathrm{HNO}_{2}\right] .
\end{aligned}
$$

Within the range of normal oceanic $\mathrm{pH}$, and especially in oligotrophic waters, the majority of alkalinity in seawater is found in the form of dissolved inorganic carbon (DIC) as $\mathrm{HCO}_{3}^{-}$and $\mathrm{CO}_{3}^{2-}$ (Millero, 1979; Wolf-Gladrow et al., 2007).

The dissolution and precipitation of carbonate minerals, both biotic and abiotic, can alter the water column TA within coral reef lagoons (Andersson et al., 2007; Rao et al., 2012). These changes in TA are large enough that ecosystem calcification rates have historically been measured using the alkalinity anomaly technique (Chisholm and Gattuso, 1991; Gattuso et al., 1996), which relies on measuring the change in water column TA according to the following equation:

$\mathrm{CaCO}_{3} \leftrightarrow \mathrm{Ca}^{2+}+\mathrm{CO}_{3}^{2-}$.

Because $\mathrm{CO}_{3}^{2-}$ is equal to 2 TA equivalents, calcification rates are equal to half the change of TA concentrations.

TA measurements are widely used in ocean acidification research to quantify community calcification rates (Shamberger et al., 2011; Silverman et al., 2012), measure sediment precipitation and dissolution rates (Andersson et al., 2007; Cyronak et al., 2013), correct net ecosystem production calculations for inorganic carbon contributions (Frankignoulle et al., 1996; Gattuso et al., 1996; Suzuki and Kawahata, 2003), and to measure reef dissolution and bioerosion (Lazar and Loya, 1991; Zundelevich et al., 2007; Manzello et al., 2008). Also, it has been suggested that alkalinity generated from sediment dissolution may act as a partial buffer against any decrease in $\mathrm{pH}$ associated with ocean acidification, (Kleypas and Langdon, 2006; Morse et al., 2006), although this buffering capacity is still being debated (see Andersson and Mackenzie, 2012). The importance of TA in ocean acidification research makes it important to constrain all sources and sinks of TA within coral reef ecosystems.

The exchange of solutes between the water column and permeable carbonate sediments is driven mainly by advective processes (Precht and Huettel, 2003; Santos et al., 2012). Flow- and topography-induced porewater exchange (see Fig. 1 in Santos et al., 2012) is probably the dominant process driving porewater exchange within coral reef lagoons due to the formation of ripples and crests within permeable carbonate sediments (Precht and Huettel, 2003). This process acts on short temporal (minutes to hours) and small spatial scales $(\mathrm{cm})$ to induce the exchange of porewater solutes with the overlying water column (Precht and Huettel, 2003). Pore-
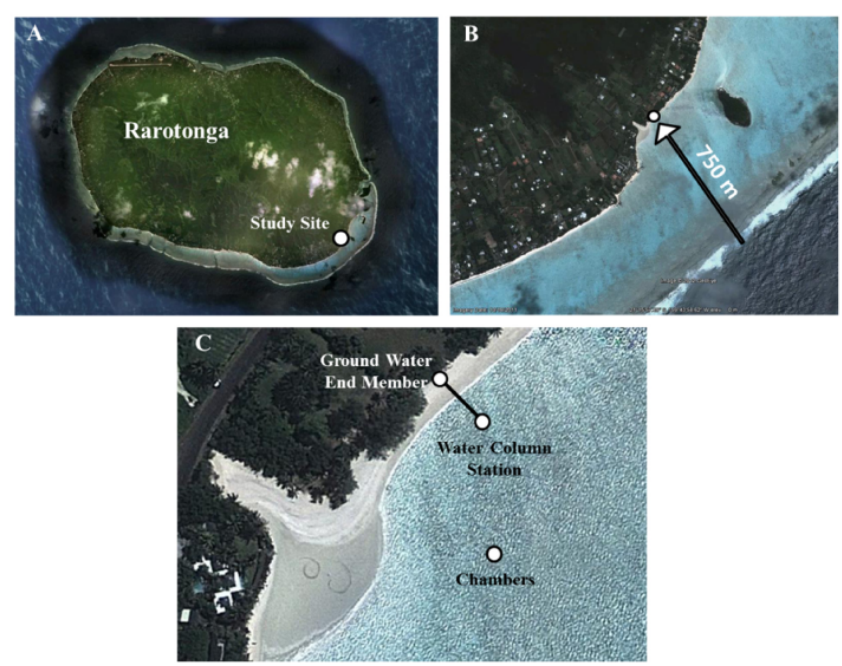

Fig. 1. A map of Rarotonga showing the location of Muri Lagoon and the study site.

water advection has a stimulatory effect on biological processes occurring within the sediments (Cook and Røy, 2006; Eyre et al., 2008; Glud et al., 2008) and has also been shown to have a stimulatory effect on TA fluxes, with increasing advection rates increasing net daily TA fluxes (Rao et al., 2012; Cyronak et al., 2013). However, while coral reef community calcification rates are negatively correlated with the aragonite saturation state $\left(\Omega_{\mathrm{Ar}}\right)$ of the water column (see Fig. 6 in Shamberger et al., 2011), carbon cycling in permeable sediments cannot be easily predicted by the $\Omega_{\mathrm{Ar}}$ of the overlying water (Cyronak et al., 2013).

Submarine groundwater discharge (SGD) has been shown to be in an important component of freshwater delivery to coastal ecosystems, on the scale of $6 \%$ to $10 \%$ of surface water flow, which amounts to an estimated $10000 \mathrm{~L} \mathrm{~m}^{-1} \mathrm{~d}^{-1}$ along the global coast (Burnett et al., 2003; Santos et al., 2012). The few studies assessing SGD rates on coral reefs describe a range from 52 to $4732 \mathrm{~L} \mathrm{~m}^{-1} \mathrm{~h}^{-1}$, and suggest that SGD can be an important source of solutes to coral reef ecosystems (Lewis, 1987; D'Elia and Wiebe, 1990; Paytan et al., 2006; Knee et al., 2010; Blanco et al., 2011). There are multiple methods to estimate SGD into coastal ecosystems including seepage meters, piezometers, natural tracers, water balance approaches, and theoretical modeling (Burnett et al., 2006). Due to its naturally high concentrations in groundwater compared to surface waters, and its unreactive nature, ${ }^{222} \mathrm{Rn}$ has been used as a natural tracer for groundwater in aquatic systems for decades (Cable et al., 1996; Burnett et al., 2006). Mass balance models using ${ }^{222} \mathrm{Rn}$ have been developed that estimate SGD fluxes into coastal ecosystems (Burnett and Dulaiova, 2003).

Groundwater concentrations of TA can be higher than oceanic waters and encompass a broad range from 90 to $23300 \mu \mathrm{mol} \mathrm{L}^{-1}$ (Mahlknecht et al., 2004; Rad et al., 2007; 
Moore et al., 2011; Schopka and Derry, 2012). Using radiumbased SGD efflux rates, Moore et al. (2011) demonstrated that SGD is a source of alkalinity to the water column in the Wadden Sea. Therefore, groundwater exchange processes occurring on larger temporal and spatial scales than flow-induced advective exchange also have the potential to deliver TA to coral reef lagoons. In fact, Kleypas and Langdon (2006) postulated that ocean acidification may be buffered against in coral reef ecosystems through the exchange of groundwater. The ability of groundwater to act as a source of TA to coral reef lagoons is highly dependent on the exchange rates with the water column, which can have large temporal and spatial variation (Lewis, 1987; Burnett et al., 2003; Santos et al., 2012). Determining the sources and sinks of alkalinity to coral reef ecosystems from groundwater and porewater exchange mechanisms is important in constraining how increasing $p \mathrm{CO}_{2}$ will impact seawater carbonate chemistry within coral reef ecosystems.

The hypothesis of this study is that two groundwater sources will contribute TA to Muri Lagoon, a fringing coral reef lagoon in the Cook Islands. To test this hypothesis, advective, benthic incubations were used to determine the influence of porewater advection on alkalinity fluxes from permeable sediments over short temporal and spatial scales (herein referred to as porewater fluxes). Measurements of ${ }^{222} \mathrm{Rn}$ were also undertaken to determine the input of alkalinity from larger temporal and spatial scale groundwater exchange (herein referred to as SGD or groundwater). While "porewater" and "groundwater" are technically synonymous (i.e., any water in contact with geological materials), the hydrology and oceanography communities tend to refer to porewater as a shallow interstitial water and groundwater as deeper, fresher water (Burnett et al., 2003, 2006).

\section{Materials and methods}

\subsection{Study site}

Our study site was located on the island of Rarotonga, a South Pacific, volcanic island within the archipelago of the Cook Islands. Rarotonga is the largest island in the Cook Islands group $\left(67 \mathrm{~km}^{2}\right)$ and made up of volcanic rocks that are comprised of $42 \%$ to $53 \% \mathrm{SiO}_{2}$ and $2 \%$ to $14 \% \mathrm{CaO}$ (Waterhouse et al., 1986). Rarotonga has a rainy (November to April) and dry (May to October) season, with average annual rainfall of $1900 \mathrm{~mm} \mathrm{yr}^{-1}$ (Thompson, 1986). Muri Lagoon is a fringing, coral reef lagoon located along the southwestern coast of Rarotonga (Fig. 1). The study site was divided into two locations within Muri Lagoon: one where the chamber incubations were performed and the second where the water column monitoring station was set up (Fig. 1). The chamber sampling site was located further $(\sim 75 \mathrm{~m})$ from shore to minimize any SGD impact and because of the large area of carbonate sediments free from macrophytes. The moni- toring station consisted of multiple probes and a bilge pump connected to a cinder block roughly $10 \mathrm{~m}$ offshore from the low tide mark. The lagoon extended $\sim 750 \mathrm{~m}$ offshore to the reef crest from our monitoring station (Fig. 1). Muri Lagoon has an average depth of about $1.4 \mathrm{~m}$ and covers an area of $1.75 \mathrm{~km}^{2}$ (Holden, 1992). The flow in Muri Lagoon is dominated by wave setup and runs from the reef crest towards shore, and then northeast along the shore towards a channel that opens to the ocean (Holden, 1992). The tidal cycle in Muri Lagoon is semi-diurnal with an average range of $1 \mathrm{~m}$. The tidal range during our sampling period was $0.4 \mathrm{~m}$ and was towards the end of a spring tide cycle.

Sediment in the lagoon has a hydraulic conductivity of $\sim 17.3 \mathrm{~m}^{-1} \mathrm{~d}^{-1}$, which equates to a permeability of approximately $1.91 \times 10^{-11} \mathrm{~m}^{2}$. Sediment grain size was $5.8 \%$ $>2 \mathrm{~mm}, 16.5 \%$ between $1-2 \mathrm{~mm}, 19.4 \%$ between $500 \mu \mathrm{m}-$ $1 \mathrm{~mm}, 30.6 \%$ between $250 \mu \mathrm{m}-500 \mu \mathrm{m}, 25.0 \%$ between $125 \mu \mathrm{m}-250 \mu \mathrm{m}, 2.5 \%$ between $63 \mu \mathrm{m}-125 \mu \mathrm{m}$, and $0.2 \%$ $<63 \mu \mathrm{m}$. Bulk carbonate sediments were composed of $0.5 \%$ calcite, $0.7 \%$ quartz, $26.3 \% \mathrm{Mg}$ calcite $(15.5 \% \mathrm{Mg}$ content), and $71.9 \%$ aragonite as determined by X-ray diffraction analysis. Visual inspection of the sediments revealed black coloration a few $\mathrm{cm}$ below the surface, which is typical of high sulfide concentrations.

\subsection{Advective chamber sampling and porewater fluxes}

Chambers identical to those described in Glud et al. (2008) and Eyre et al. (2008) were used to measure in situ benthic solute fluxes at three different advection rates. Three chambers were inserted $15 \mathrm{~cm}$ into the sediment and enclosed roughly $4 \mathrm{~L}$ of overlying seawater during the incubations. Advection was induced within the chambers based on the spinning rate, in rotations per minute (RPM), of the acrylic disk within each chamber (diffusive, 40 RPM, and 60 RPM). Three stirring rates were chosen in order to investigate any effect of advection on alkalinity flux rates, similar to studies done in other coral lagoons (Glud et al., 2008; Cyronak et al., 2013). In order to maintain a homogenous distribution of solutes within the diffusive chamber, it was operated with the disk slowly spinning clockwise for one rotation, then pausing and spinning counter clockwise for one rotation and repeating (Glud et al., 2008). Incubations were run concurrently with the water column sampling, starting at 07:00 LT on 17 March 2012 and lasting for $28.5 \mathrm{~h}$. Samples of $150 \mathrm{~mL}$ were drawn by syringe with ambient seawater allowed to replace the sample volume. The sample volume removed represented a minor percentage of the volume within the chambers $(<4 \%)$ and therefore was unlikely to greatly influence chamber solute concentrations. Flux rates from the chambers were calculated using the integral-based technique as described in Cyronak et al. (2013). Negative numbers represent a flux into the sediments, while positive numbers represent fluxes of solutes out of the sediments. In order to compare advective flux rates to ${ }^{222} \mathrm{Rn}$-derived SGD 
flux rates, averages between the two advective stirring rates (40 and 60 RPM) were used (discussed in detail later).

\subsection{Water column sampling}

Discrete samples were taken every $2 \mathrm{~h}$ from the water column along with the monitoring of physico-chemical parameters every $5 \mathrm{~min}$ using a multi-probe. A Hydrolab DS5X (Hach Environmental) was deployed $0.2 \mathrm{~m}$ from the bottom and $10 \mathrm{~m}$ offshore of the low tide mark to monitor temperature $( \pm 0.5 \%)$, PAR $( \pm 5 \%)$, and salinity $( \pm 0.5 \%)$ every 5 min. Depth was measured using an In-Situ Inc. Aqua Troll 200. For the monitoring data, an average over $1 \mathrm{~h}$ (30 min before and after) was taken over half-hour intervals in order to smooth the data and better reveal any trends. Sampling of the water column started at 7:00 LT on 17 March 2012 and lasted for $28.5 \mathrm{~h}$. Discrete water samples were taken using $150 \mathrm{~mL}$ plastic syringes and brought back to lab to measure salinity, DO, TA, $\delta^{13} \mathrm{C}$ DIC, and $\mathrm{pH}$.

In order to measure ${ }^{222} \mathrm{Rn}$ concentrations in the water column, a submersible bilge pump continuously pumped seawater to an onshore gas equilibration device (GED) at about $2 \mathrm{~L} \mathrm{~min}-1$. The GED equilibrates gas through a shower head exchanger similar to that described in Burnett et al. (2001). Air was recirculated through a closed loop from the GED into a RAD7 ${ }^{222} \mathrm{Rn}$ detector in order to monitor ${ }^{222} \mathrm{Rn}$ concentrations every $30 \mathrm{~min}$ (Burnett et al., 2001). In order to generate a groundwater endmember for ${ }^{222} \mathrm{Rn}$-derived flux calculations, a bore was dug $10 \mathrm{~m}$ onshore of the high tide mark and piezometers were inserted to depths of $1 \mathrm{~m}$ and $2.5 \mathrm{~m}$. Discrete samples were taken from the $1 \mathrm{~m}$ piezometer at 3 separate times during the study, and one sample was taken from the $2.5 \mathrm{~m}$ piezometer. To measure the ${ }^{222} \mathrm{Rn}$ endmember of groundwater, a peristaltic pump was used to pump water from the piezometers at $1 \mathrm{~L} \mathrm{~min}^{-1}$ into the GED. The ${ }^{222} \mathrm{Rn}$ concentrations were allowed to equilibrate and then measured for 1 to $4 \mathrm{~h}$ with the average concentration during that time used as the groundwater endmember. Gas permeable silicone tubing was only used in the pump head in order to minimize any losses of ${ }^{222} \mathrm{Rn}$. Laboratory experiments revealed no differences in concentrations when using a peristaltic pump and other pumps to feed the exchanger.

We used a non-steady-state ${ }^{222} \mathrm{Rn}$ mass balance model from Burnett and Dulaiova (2003) to determine groundwater flux rates in $\mathrm{cm}^{3} \mathrm{~m}^{-2} \mathrm{~d}^{-1}$. The model incorporated sources of ${ }^{222} \mathrm{Rn}$ from groundwater balanced by losses due to atmospheric evasion as a function of wind speed, mixing, and radioactive decay. The alkalinity of the mixed endmember (discussed in detail later) was multiplied by the flux rates generated by the model in order to get ${ }^{222} \mathrm{Rn}$-derived fluxes of groundwater TA into the lagoon. Both the advective TA fluxes and ${ }^{222} \mathrm{Rn}$-derived TA fluxes were calculated at the sampling locations and extrapolated along a $750 \mathrm{~m}$ transect to the reef crest (discussed in detail later).

\subsection{Sample analysis}

Both water column and benthic chamber samples were immediately brought back into the laboratory. Dissolved oxygen $( \pm 1 \%)$ was measured directly following collection using a Hach Luminescent Dissolved Oxygen $\left(\mathrm{LDO}^{\circledR}\right)$ probe. Samples for nutrients were filtered with a $0.45 \mu \mathrm{m}$ cellulose acetate filter and frozen at $-20^{\circ} \mathrm{C}$ until analyzed following the methods of Eyre and Ferguson (2005) using a Lachat flow injection analysis (FIA) system. Samples for TA and $\mathrm{pH}$ were filtered through a $0.45 \mu \mathrm{m}$ cellulose acetate filter and stored in an airtight container with no headspace until analysis within $4 \mathrm{~h}$ of sampling. $\mathrm{pH}( \pm 0.003)$ was measured using a Metrohm Electrode Plus calibrated to Oakton National Bureau of Standards (NBS) standards of 4, 7, and 10. To determine TA, Gran titrations were performed using a Metrohm Titrando automatic titrator and $\mathrm{pH}$ electrode. Prestandardized $0.01 \mathrm{~mol} \mathrm{~L}^{-1} \mathrm{HCl}$ was used as the titrant, which was calibrated against Dickson certified reference material (Batch 111). Alkalinity samples were run twice, and the average of the two values was used. During the study the \% CV of duplicate TA measurements was $0.15 \%$.

Samples for $\delta^{13} \mathrm{C}$ DIC (analytical error of $\pm 0.1 \%$ ) were $0.7 \mu \mathrm{m}$ filtered with a Whatman GF/F syringe filter, preserved using $50 \mu \mathrm{L}$ of saturated $\mathrm{HgCl}$ with no head space, and stored at $4{ }^{\circ} \mathrm{C} . \delta^{13} \mathrm{C}$ DIC was measured in order to separate any sources of TA and DIC in the groundwater and water column. Samples were acidified with $5 \%(v / v)$ phosphoric acid, and the resulting $\mathrm{CO}_{2}$ was analyzed via continuous flow wetoxidation isotope ratio mass spectrometry (CF-WO-IRMS) using an Aurora 1030W total organic carbon (TOC) analyzer coupled to a Thermo Delta V Plus IRMS (Oakes et al., 2010). DIC concentrations and $W_{\text {Ar }}$ were estimated with the Excel macro $\mathrm{CO}_{2}$ System (CO2SYS) (Pierrot et al., 2006) using inputs of TA and $\mathrm{pH}$ and the constants from Mehrbach et al. (1973) refit by Dickson and Millero (1987) and $W_{\mathrm{Ar}}$. Data from Cyronak et al. (2013) showed excellent agreement between measured and calculated DIC concentrations using the same inputs into CO2SYS as this study. Carbonate alkalinity $\left(\mathrm{TA}_{\mathrm{C}}\right)$ for the chamber samples was calculated by subtracting the alkalinity, as determined in CO2SYS, contributed by $\mathrm{B}(\mathrm{OH})_{4}^{-}, \mathrm{OH}^{-}$and total dissolved phosphorus (TDP) from TA.

\section{Results}

\subsection{Advective chambers}

The flux rates of $\mathrm{TA}_{\mathrm{C}}$, DIC, DO, and $\mathrm{H}^{+}$from the chambers are shown in Fig. 2. All of the rates follow a distinct diel pattern that is consistent with biological activity acting as the driver of solute fluxes from permeable sediments. Flux rates of $\mathrm{TA}_{C}$ decreased throughout the day and began to increase in the late afternoon (Fig. 2a). TA ${ }_{C}$ flux rates became 

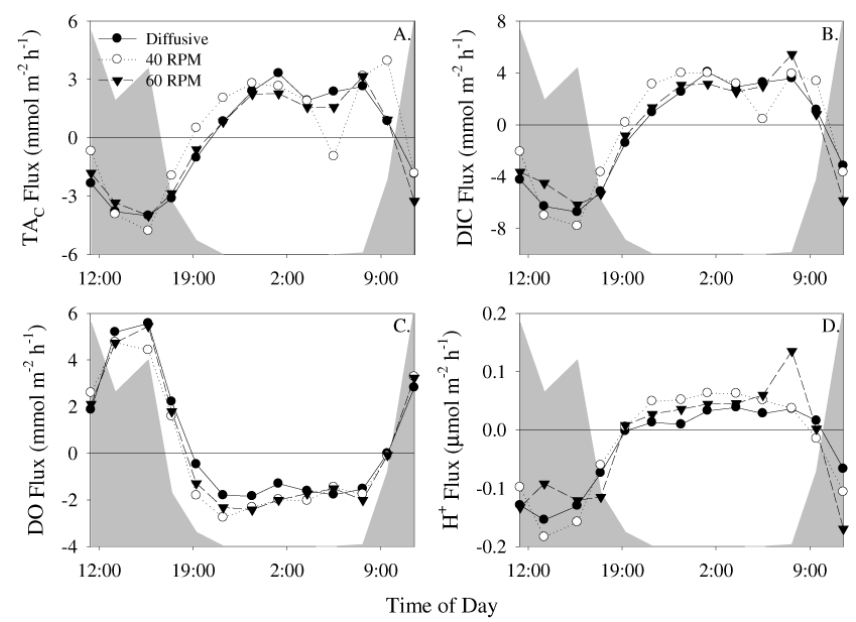

Fig. 2. Hourly, integral-derived flux rates of $\mathrm{TA}_{\mathrm{C}}$, DIC, DO and $\mathrm{H}^{+}$from the advective chambers. The grey filled area in the background is PAR over the course of the incubations. All fluxes are in mmol m${ }^{-2} \mathrm{~h}^{-1}$ besides $\mathrm{H}^{+}$, which are in $\mu \mathrm{mol} \mathrm{m} \mathrm{m}^{-2} \mathrm{~h}^{-1}$.

positive around sunset and increased until midnight, and then varied slightly for the rest of the night until becoming negative in the morning. DIC flux rates showed a similar pattern to $\mathrm{TA}_{\mathrm{C}}$ (Fig. 2b). DO and $\mathrm{H}^{+}$flux rates followed the opposite pattern of DIC and TAC fluxes (Fig. 2). DO fluxes increased throughout the morning then decreased in the late afternoon, becoming negative around sunset and levelling off during the night (Fig. 2c). $\mathrm{H}^{+}$fluxes showed the same trend as DO fluxes with slight variation in the night (Fig. 2d). Figure 3 shows the hourly flux rates of $\mathrm{TA}_{\mathrm{C}}$, DIC, and DO plotted against the average photosynthetic active radiation (PAR) measured during the same time as the flux was calculated. All three solutes show a distinct hysteretic pattern, with lower rates of all fluxes in the morning at comparable PAR levels in the afternoon (Fig. 3). The fluxes of TA $\mathrm{C}_{\mathrm{C}}$ in the $40 \mathrm{RPM}$ chamber showed the largest variation between the morning and afternoon (Fig. 3).

\subsection{Water column time series}

The water column time series was conducted over two tidal cycles and one diel cycle (Fig. 4). Salinity fluctuated throughout the day, and the lowest salinities occurred during the low tides (Fig. $4 \mathrm{a}$ and $\mathrm{b}$ ). DO concentrations and $\Omega_{\mathrm{Ar}}$ followed a trend that was consistent with diel variation driven by biological processes, and throughout the course of the day $\Omega_{\mathrm{Ar}}$ varied from 2.3 to 4.4 (Fig. $4 \mathrm{e}$ and f). In contrast, TA had a complex dynamics that was related to both diel and tidal cycles, supported by the variation in TA concentrations measured over one diel cycle and two tidal cycles (Fig. 4c). DIC concentration showed a similar trend to TA while the $\delta^{13} \mathrm{C}$ of DIC followed the opposite trend, decreasing with any increase in [DIC] (Fig. 4d). During sampling, ${ }^{222} \mathrm{Rn}$ concentra-

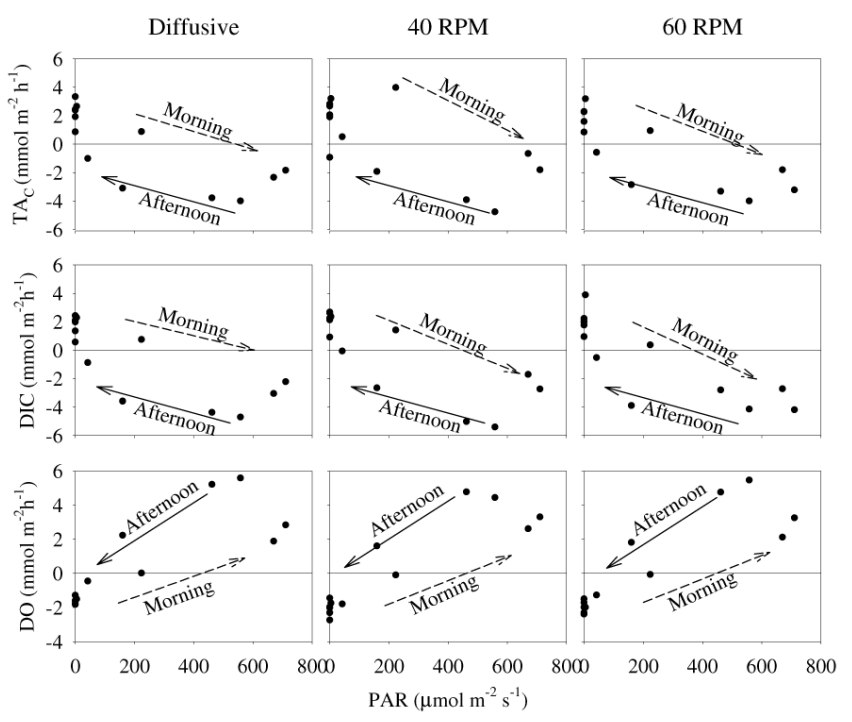

Fig. 3. Flux rates of $\mathrm{TA}_{C}$, DIC, and DO plotted against the average PAR values measured during the same time period as the flux. Flux rates are in $\mathrm{mmol} \mathrm{m}^{-2} \mathrm{~h}^{-1}$.

tions in the water column varied between $7471 \mathrm{dpm} \mathrm{m}^{-3}$ and $16040 \mathrm{dpm} \mathrm{m}^{-3}$, and were highest during low tides (Fig. 5).

\subsection{Groundwater endmembers}

Groundwater measured from piezometers at $1 \mathrm{~m}$ and $2.5 \mathrm{~m}$ was fresh but differed in solute composition (Table 1). The water chemistry in the three samples taken from the $1 \mathrm{~m}$ well did not vary much between the different sampling times, so we reported the average (see Table 1). The DIC concentrations were about twice as high in the shallower groundwater than in the deeper groundwater while $\delta^{13} \mathrm{C}$ DIC was more enriched in the deeper groundwater. TA was $7134 \mu \mathrm{mol} \mathrm{L}^{-1}$ in the shallow groundwater and $3989 \mu \mathrm{mol} \mathrm{L}^{-1}$ in the deeper groundwater. However, ${ }^{222} \mathrm{Rn}$ concentrations showed the opposite trend of the solutes, with concentrations in the deeper groundwater roughly 6 times higher than in the shallow groundwater. The $\mathrm{pH}$ of the shallow groundwater was lower than the deeper groundwater. We suspect that the discharging groundwater represents a mixture of these two and potentially other groundwater endmembers.

\section{Discussion}

\subsection{Diel cycling of TA in advective chambers}

Hourly flux rates of $\mathrm{TA}_{\mathrm{C}}$, DIC, DO, and $\mathrm{H}^{+}$followed trends that were consistent with biological activity driving the fluxes of those solutes over a diel cycle (Fig. 2). During the day, flux rates of all solutes were greatest, whether negative or positive, in the afternoon at the 15:30 LT sampling point (Fig. 2). This is consistent with the availability of PAR driving rates 
Table 1. Measurements of solutes in the groundwater endmembers (EM), EM1 $n=3$, EM2 $n=1 . \delta^{13} \mathrm{C}$ DIC of the mixed endmember was estimated from the y-intercept of a Keeling plot. The 47\% EM1:53\% EM2 is the concentration calculated from the $\delta^{13} \mathrm{C}$ DIC-estimated endmember values.

\begin{tabular}{lrrrrrr}
\hline & Depth $(\mathrm{m})$ & $\mathrm{DIC}\left(\mu \mathrm{mol} \mathrm{L}{ }^{-1}\right)$ & $\delta^{13} \mathrm{C} \mathrm{DIC}$ & $\mathrm{TA}\left(\mu \mathrm{mol} \mathrm{L}{ }^{-1}\right)$ & ${ }^{222} \mathrm{Rn}\left(\mathrm{dpm} \mathrm{m}{ }^{-3}\right)$ & $\mathrm{pH}$ \\
\hline Groundwater EM1 & 1 & $9381 \pm 354$ & $-10.1 \pm 1.0$ & $7134 \pm 60$ & $49585 \pm 1743$ & 7.325 \\
Groundwater EM2 & 2.5 & 4251 & -6.3 & 3989 & $294146 \pm 4601$ & 7.593 \\
$47 \%$ EM1 : 53\% EM2 & - & 6661 & -8.10 & 5467 & 179202 & 7.480 \\
\hline
\end{tabular}

Table 2. Maximum hourly uptake and efflux rates of $\mathrm{TA}_{\mathrm{C}}$ measured from advective benthic chambers in this study compared to a similar study on the Great Barrier Reef. Daily flux rates of $\mathrm{TA}_{\mathrm{C}}$ are also shown.

\begin{tabular}{|c|c|c|c|c|c|}
\hline Location & Chamber & $\begin{array}{c}\text { TA }_{\mathrm{C}} \text { Efflux } \\
\left(\mathrm{mmol} \mathrm{m}^{-2} \mathrm{~h}^{-1}\right)\end{array}$ & $\begin{array}{c}\text { TA }_{\mathrm{C}} \text { Uptake } \\
\left(\mathrm{mmol} \mathrm{m}^{-2} \mathrm{~h}^{-1}\right)\end{array}$ & $\begin{array}{l}\text { Daily } \text { TA }_{C} \text { Flux } \\
\left(\mathrm{mmol} \mathrm{m}^{-2} \mathrm{~d}^{-1}\right)\end{array}$ & Source \\
\hline \multirow{3}{*}{ Cook Islands } & Diffusive & 3.32 & -4.01 & -1.16 & \multirow{3}{*}{ This study } \\
\hline & $40 \mathrm{RPM}$ & 3.96 & -4.78 & 7.76 & \\
\hline & $60 \mathrm{RPM}$ & 3.17 & -4.01 & -1.55 & \\
\hline \multirow{3}{*}{ Heron Island } & Diffusive & 5.21 & -4.83 & 5.13 & \multirow{3}{*}{ Cyronak et al. (2013) } \\
\hline & $40 \mathrm{RPM}$ & 4.93 & -5.65 & 8.84 & \\
\hline & $80 \mathrm{RPM}$ & 5.61 & -7.36 & 8.78 & \\
\hline
\end{tabular}

of benthic photosynthesis. Photosynthesis would alter the chemistry of porewaters by taking up DIC and releasing DO into the porewaters, thereby affecting both flux rates of $\mathrm{TA}_{\mathrm{C}}$ (by promoting carbonate precipitation) and $\mathrm{H}^{+}$, while respiration would have the opposite effect (Cook and Røy, 2006; Cyronak et al., 2013). Efflux rates of $\mathrm{TA}_{\mathrm{C}}$ in the morning indicate that dissolution of carbonates is still occurring until the late morning when the sediments shift to TA $\mathrm{C}_{\mathrm{C}}$ uptake. During the nighttime, the flux rates of all solutes tended to level off after the transition between light and dark (Fig. 2). This is probably due to the shift in biological activity from production to respiration and the associated changes in porewater chemistry.

Maximum hourly $\mathrm{TA}_{\mathrm{C}}$ uptake and efflux rates were similar between all three chambers (Table 2). When compared to flux rates obtained from identical chambers in Heron Island (Australia), fluxes from the Cook Islands were generally lower (Table 2). Also uptake rates were stimulated by advection in Heron Island, whereas $\mathrm{TA}_{\mathrm{C}}$ uptake rates in the Cook Islands were similar between the stirring rates. The exact mechanisms behind these differences are unknown, but visual inspection of the two sediments revealed less biota (e.g., calcareous algae and fauna) in the Cook Island sediments. Lower amounts of benthic fauna would decrease any biologically driven stimulatory effect of advection on benthic fluxes (Cook and Røy, 2006; Cyronak et al., 2013). In addition, the black reducing layer apparent in the Cook Island sediments was not present in Heron Island. As advection delivers oxygen to this layer, it may lower the TA concentrations in the porewaters due to sulfide oxidation ( $\mathrm{Ku}$ et al., 1999). This is consistent with reduced benthic fluxes in the
60 RPM chamber, which would deliver oxygen deepest into the sediments.

Grain size of the sediment was generally smaller in the Cook Islands, with the highest percentage between 250$500 \mu \mathrm{m}$ compared to Heron Island, which was mostly in the 1-2 $\mathrm{mm}$ range. Even though permeability was similar (Glud et al., 2008), differences in grain size may affect the flow of water through the sediments and subsequent TA fluxes. Daily fluxes of TA from the sediments ranged from -1.55 to $7.76 \mathrm{mmol} \mathrm{m}^{-2} \mathrm{~d}^{-1}$, with the highest rates in the $40 \mathrm{RPM}$ chamber (Table 2). Although hourly rates between the three chambers were similar (Fig. 2), integrated daily rates in the 40 RPM chamber were higher than both the diffusive and 60 RPM chambers. Daily Cook Island TA $C$ fluxes were lower than flux rates measured in Heron Island, although the daily TA $_{C}$ flux rates from the 40 RPM chambers were similar in magnitude.

The hysteretic pattern of solute fluxes in the advective chambers is indicative of processes in the sediments being influenced by the previous state of the system (Fig. 3). Lower fluxes in the morning than in the afternoon for TA $\mathrm{T}_{\mathrm{C}}$, DIC, and DO may be due to the decrease in DO and $\Omega_{\mathrm{Ar}}$ overnight and subsequent change in the system as photosynthesis increases DO in the porewaters (Cyronak et al., 2013). Similar patterns in coral photosynthesis and calcification have been shown over a diel cycle (Levy et al., 2004; Schneider et al., 2009). Levy et al. (2004) attributed the lower photosynthesis rates in the morning to a breakdown of photosynthetic machinery at night and subsequent buildup during the day, while the hysteresis in calcification rates was attributed to changes in respiration rates of corals at specific times during 
a diel cycle (Schneider et al., 2009). Similar processes may be occurring in the microbiota living in the sediments, which would contribute to the observed hysteresis. Also, because DO is consumed through sulfide oxidation (Ku et al., 1999), high sulfide production and the subsequent buildup in the porewaters overnight might also lead to the observed hysteresis in flux rates. If sulfide concentrations built up overnight, DO produced in the morning would be consumed in the sediments, potentially leading to the lower oxygen efflux rates observed in the morning than the afternoon (Fig. 3).

The slope of DIC vs. TA $\mathrm{C}_{\mathrm{C}}$ can be used to determine the amount of DIC that was produced due to organic or inorganic processes (Gattuso et al., 1996; Andersson and Gledhill, 2013). DIC and $\mathrm{TA}_{C}$ fluxes in the chambers were tightly correlated with an $R^{2}$ of 0.970 (Fig. 6a). The organic to inorganic ratio of the DIC flux was 2.13 as calculated from the slope in Fig. 6a. This value is lower than those reported from water column measurements but typical of sediments, possibly due to sediment porewaters being in close contact to a non-organic source (i.e., carbonates) of DIC (Gattuso et al., 1996; Cyronak et al., 2013). TA ${ }_{C}$ flux rates were well correlated with DO and DIC fluxes in the sediments (Fig. 6b and c), indicating that photosynthesis and respiration drive carbonate precipitation and dissolution. However, $\mathrm{TA}_{\mathrm{C}}$ flux rates were not as well correlated with DO fluxes (Fig. 6b) as DIC fluxes corrected for the contribution of TA due to carbonate precipitation and dissolution (Fig. 6c). This may be related to oxygen consumption by sulfides in the sediments (Ku et al., 1999). Additional investigations on the role sulfides play in alkalinity cycling in coral reef sediments are warranted.

\subsection{Estimating a mixed groundwater endmember}

When plotted against salinity, DIC concentrations in the water column showed a significant linear correlation consistent with conservative mixing between groundwater and the water column (Fig. 7). A Keeling plot, or the linear regression of $\delta^{13} \mathrm{C}$ DIC versus $1 /[\mathrm{DIC}]$, can be used to estimate the $\delta^{13} \mathrm{C}$ of DIC added to the system by calculating the y-intercept (Fig. 8) (Mortazavi and Chanton, 2004; Köhler et al., 2006; $\mathrm{Hu}$ and Burdige, 2007). The contribution of both groundwater endmembers (shallow and deep) to the water column can be estimated by using the $\delta^{13} \mathrm{C}$ of added DIC generated from the Keeling plot as the $\delta^{13} \mathrm{C}$ of the mixed endmember. The estimated contribution of the shallow and deep endmembers to the water column was $47 \%$ and $53 \%$, respectively (Table 1). The concentrations of DIC, TA, ${ }^{222} \mathrm{Rn}$, and $\mathrm{pH}$ calculated using the above percentages were used as the endmember in subsequent mixing models, which matched well to the measured groundwater values in the bores (Table 1). We recognize that since ${ }^{222} \mathrm{Rn}$ concentrations were variable with depth, the groundwater endmembers could be variable over larger spatial scales (Dulaiova et al., 2008; Santos et al., 2009). A larger number of groundwater samples could
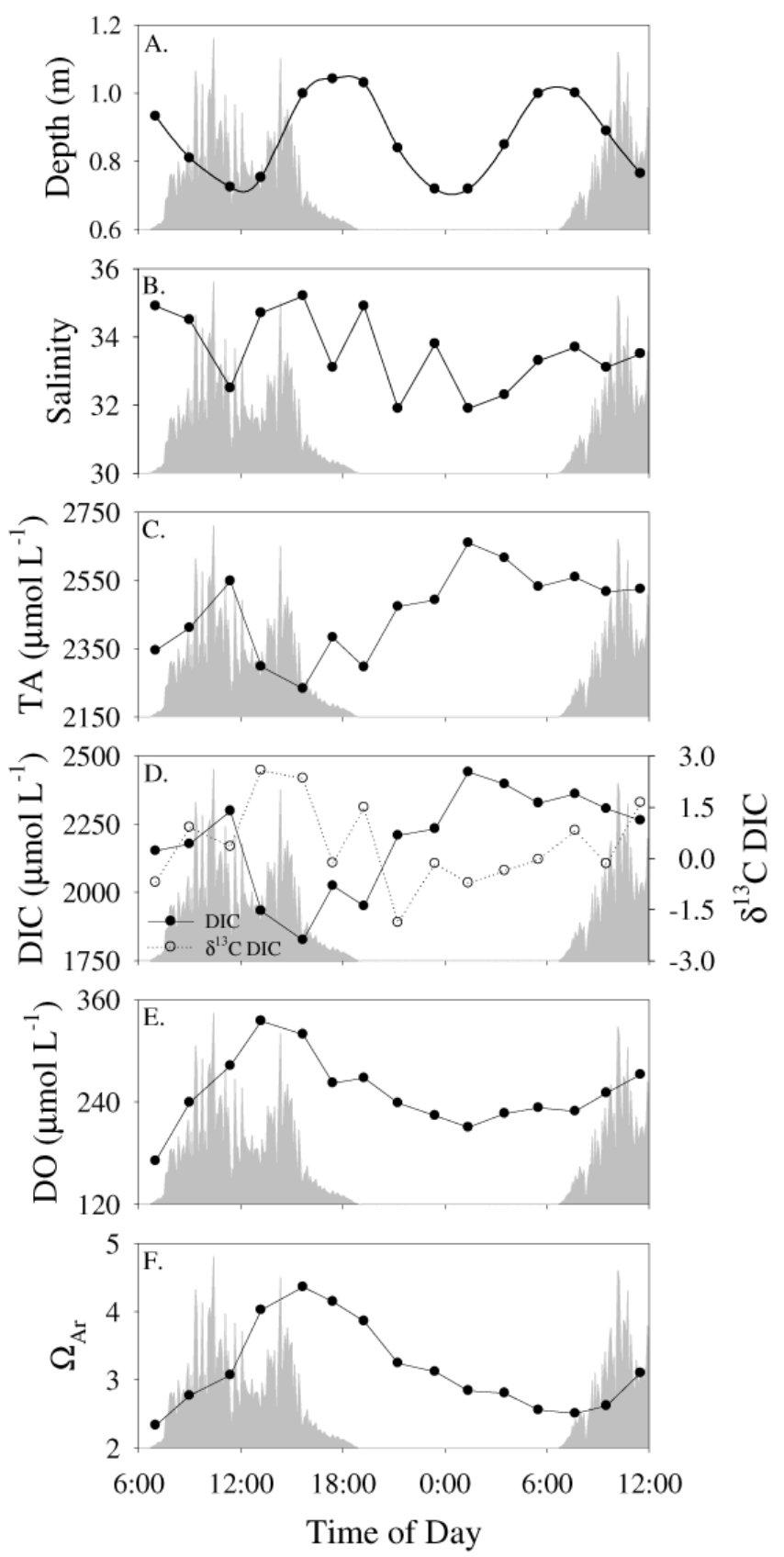

Fig. 4. (A) Depth, (B) salinity, (C) TA, (D) DIC, (E) DO, and (F) $\Omega_{A r}$ measured in the discrete water samples taken from the water column. The grey filled area in the background is PAR over the course of the study.

be important to decrease any potential uncertainties with the groundwater endmember and better elucidate fluxes over larger spatial scales.

A two-source mixing model can be used to estimate the water column concentrations of TA based on ${ }^{222} \mathrm{Rn}$ concentrations measured during the sampling period. ${ }^{222} \mathrm{Rn}$ concentrations from the water column were divided by the mixed 


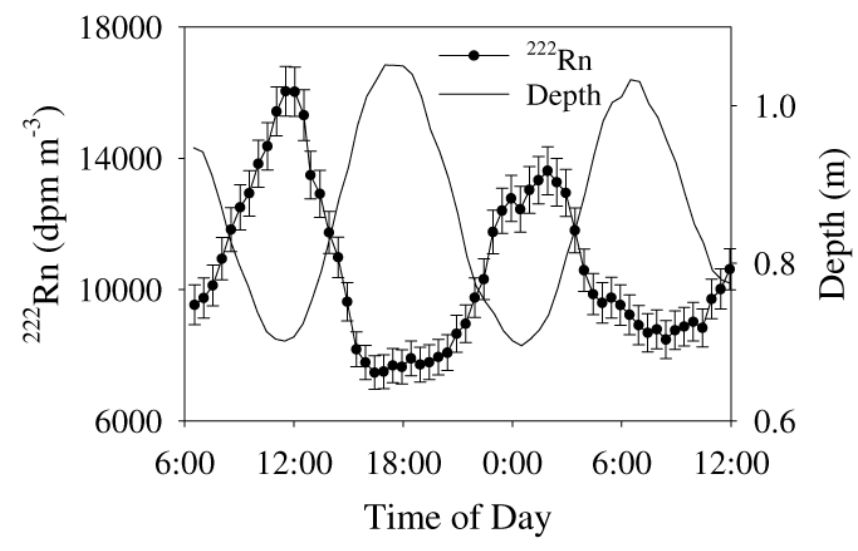

Fig. 5. ${ }^{222} \mathrm{Rn}$ concentrations and depth measured in the water column over the course of the study.

endmember concentration (47\% EM1:53\% EM2), and a percent groundwater input was then multiplied by the endmember of TA (Table 1). When a range of endmembers was used for water column TA concentrations (2100 to $2400 \mu \mathrm{mol} \mathrm{L}^{-1}$ ), which would change over the course of a day due to biological and geochemical activities (Gattuso et al., 1996; Shamberger et al., 2011), the measured concentration of TA fit within the model (Fig. 9a). A variable endmember model was also calculated based on the change in lagoonal TA concentrations over the course of a day estimated from Fig. 10. During the day, ${ }^{222} \mathrm{Rn}$ versus TA showed a different linear slope than during the night, which is consistent with carbonate precipitation being dominant during the day and dissolution during the night (Fig. 10). The initial concentration of water column TA (i.e., in the morning) was estimated as the $y$-intercept from the night regression of TA vs. ${ }^{222} \mathrm{Rn}\left(2327 \mathrm{mmol} \mathrm{L}^{-1}\right)$. Based on the difference between the $y$-intercepts for the night and day linear regressions (Fig. 10), an average rate of change for TA in the water column that excludes the effects of groundwater was estimated as $-20 \mathrm{mmol} \mathrm{m}^{-2} \mathrm{~h}^{-1}$ during the day and $20 \mathrm{mmol} \mathrm{m}^{-2} \mathrm{~h}^{-1}$ at night. When the variable endmember was applied to the water column portion of the ${ }^{222} \mathrm{Rn}$ mixing model, there was good agreement between the predicted and measured water column TA concentrations (Fig. 9b). Observed variability between the measured and predicted water column TA is probably due to diel variability in TA fluxes that are not accounted for in this model.

Because $\delta^{13} \mathrm{C}$ of DIC is depleted in the groundwater $(-6 \%$ to $-10 \%$ ) when compared to oceanic water $(0 \%$ o to $2 \%$ ) (Williams et al., 2011), and most of the TA in the groundwater is present as DIC, sources of TA to the groundwater can be inferred. The low $\delta^{13} \mathrm{C}$ values of DIC in the groundwater are indicative of an organic source of carbon, as carbonate minerals tend to have $\delta^{13} \mathrm{C}$ values from $0 \%$ to 2\%o (Weber and Woodhead, 1969; Eadie and Jeffrey, 1973; Ogrinc et al., 2003). Sulfate reduction is well known to in-
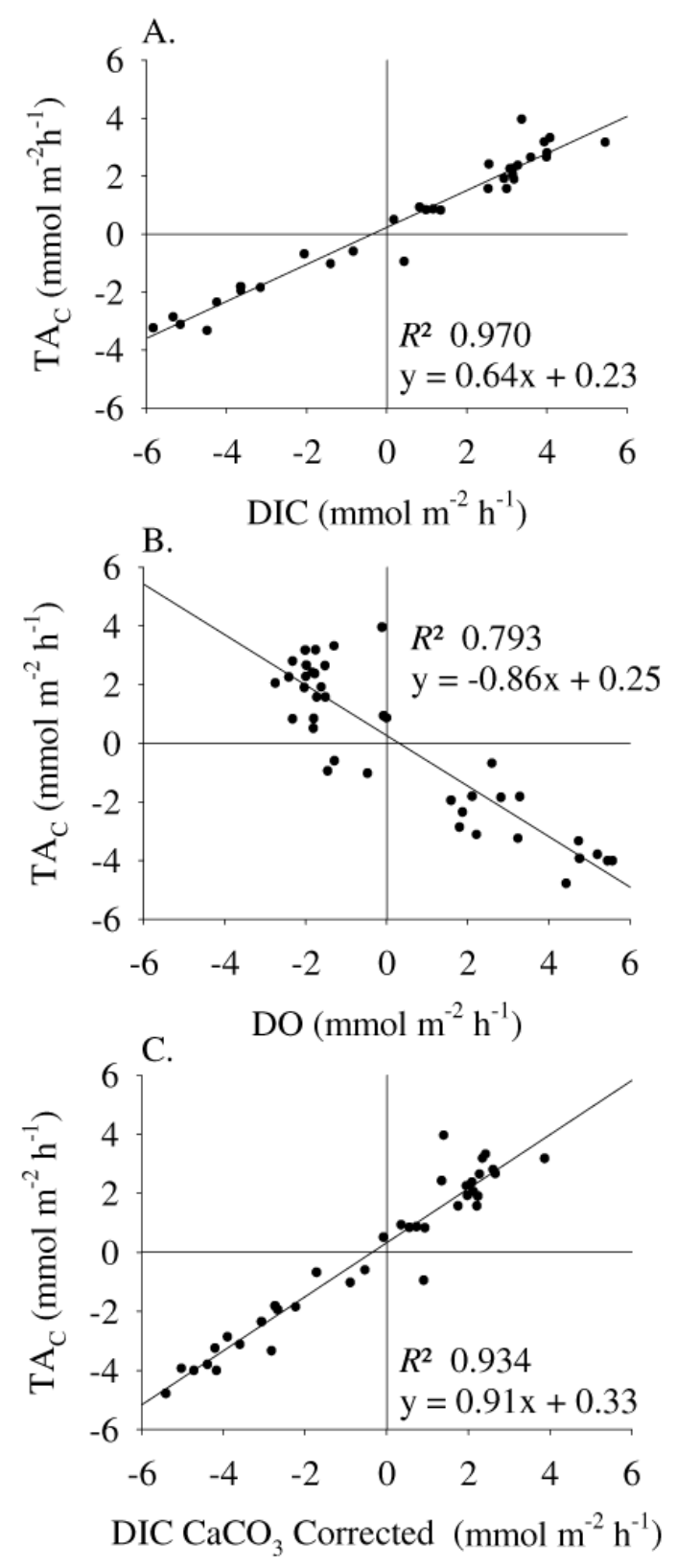

Fig. 6. Linear regressions of (A) $\mathrm{TA}_{\mathrm{C}}$ vs. DIC, (B) $\mathrm{TA}_{\mathrm{C}}$ vs. DO, and $(\mathbf{C}) \mathrm{TA}_{\mathrm{C}}$ vs. DIC corrected for $\mathrm{CaCO}_{3}$ dissolution from all stirring rates of the advective chamber incubations. Equations and $R^{2}$ values are displayed for each regression.

crease TA concentrations (Wolf-Gladrow et al., 2007), and may account for a portion of the high TA concentrations in Rarotonga groundwater. The uncoupling of sulfate reduction from sulfide oxidation would generate carbonate alkalinity with a depleted $\delta^{13} \mathrm{C}$ value due to the organic $\mathrm{C}$ source, perhaps accounting for the depleted $\delta^{13} \mathrm{C}$ DIC values found in the groundwater (Ku et al., 1999). 


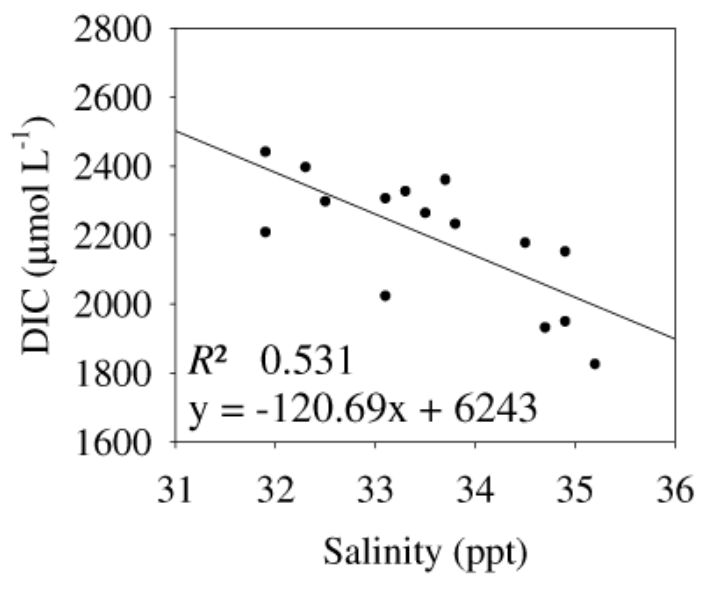

Fig. 7. Regression of salinity vs. [DIC] in the water column measured over the course of the study. The regression equation and $R^{2}$ value are displayed.

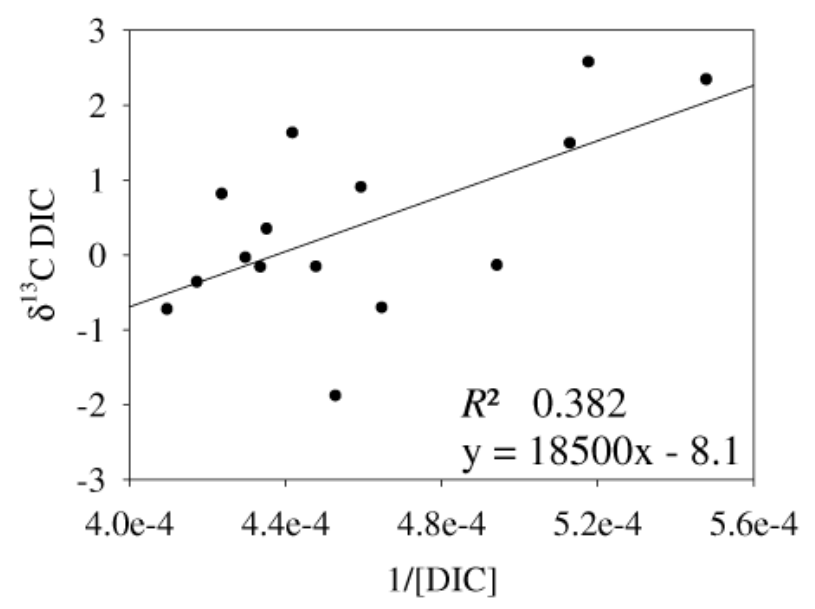

Fig. 8. Keeling plot of $\delta^{13} \mathrm{C}$ DIC vs. $1 /$ [DIC] measured in the water column.

\section{3 $\quad{ }^{222}$ Rn-derived TA groundwater fluxes}

Advection rates of groundwater into the water column were estimated using a non-steady-state ${ }^{222} \mathrm{Rn}$ mass balance model (Burnett and Dulaiova, 2003) and the concentration of ${ }^{222} \mathrm{Rn}$ estimated in the groundwater endmember (179202 $\mathrm{dpm} \mathrm{m}^{-3}$ ) (Table 1). Fluxes of groundwater ranged from 0 to $46 \mathrm{~cm} \mathrm{~d}^{-1}$ and were highest during low tides. This is consistent with steep hydraulic gradients at low tide driving fresh groundwater flow into the lagoon (Chanton et al., 2003; Kuan et al., 2012). The groundwater flux rates can be converted to an hourly basis and multiplied by the groundwater endmember concentration of TA $\left(5467 \mu \mathrm{mol} \mathrm{L}^{-1}\right)$ to estimate the fluxes of TA into the water column (Fig. 11). Fluxes ranged from 0 to $105 \mathrm{mmol} \mathrm{m}^{-2} \mathrm{~h}^{-1}$ during this study, with the highest fluxes observed during the lowest tides. The
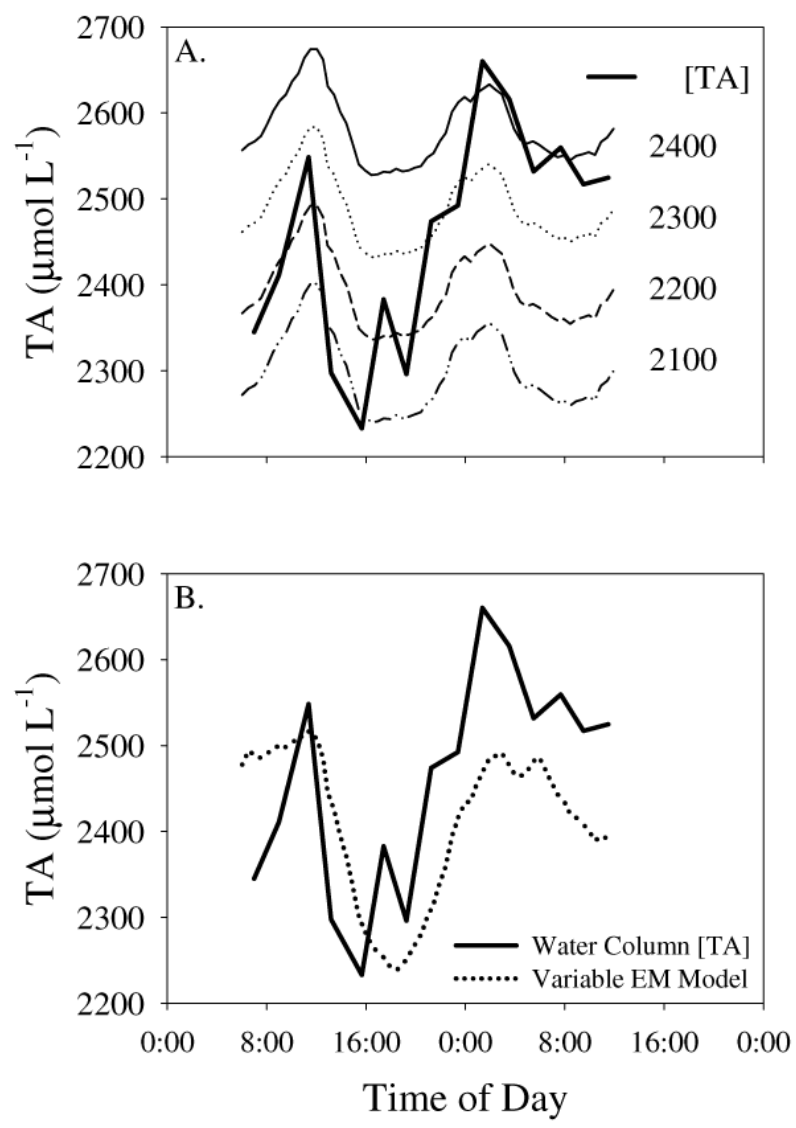

Fig. 9. Concentration of TA in the water column during the course of the study plotted along with the estimated concentration of TA based on the ${ }^{222} \mathrm{Rn}$-derived mixing models. (A) Four separate mixing models using a range of TA concentrations for the lagoonal endmember from $2100-2400 \mu \mathrm{mol} \mathrm{L}^{-1}$, (B) the variable lagoonal endmember model. All TA concentrations are in $\mu \mathrm{mol} \mathrm{L}{ }^{-1}$.

average daily ${ }^{222} \mathrm{Rn}$-derived TA flux measured during this study was $1080 \mathrm{mmol} \mathrm{m}^{-2} \mathrm{~d}^{-1}$ at the sampling site. These flux rates are most likely spatially variable throughout the lagoon, with the highest flux rates found close to shore where SGD is most influential.

The ${ }^{222} \mathrm{Rn}$-derived TA fluxes are high when compared to other TA sources and sinks in coral reef environments (Gattuso et al., 1998; Shamberger et al., 2011). However, the hourly flux rates agree well with flux rates that are needed to explain the observed changes in water column TA concentrations. Flux rates needed to account for the observed increases in TA concentrations during the day were as high as $103 \mathrm{mmol} \mathrm{m}^{-2} \mathrm{~h}^{-1}$. These values are comparable to the SGD-derived TA fluxes calculated from the ${ }^{222} \mathrm{Rn}$ mass balance and groundwater TA concentrations, which ranged from 0 to $105 \mathrm{mmol} \mathrm{m}^{-2} \mathrm{~h}^{-1}$ (Fig. 11). The fact that these two independent calculations, agree well lends support to hourly and daily ${ }^{222} \mathrm{Rn}$-derived SGD TA fluxes. Also, TA concentrations at our study site were elevated (up to $2608 \mu \mathrm{mol} \mathrm{L}^{-1}$; 


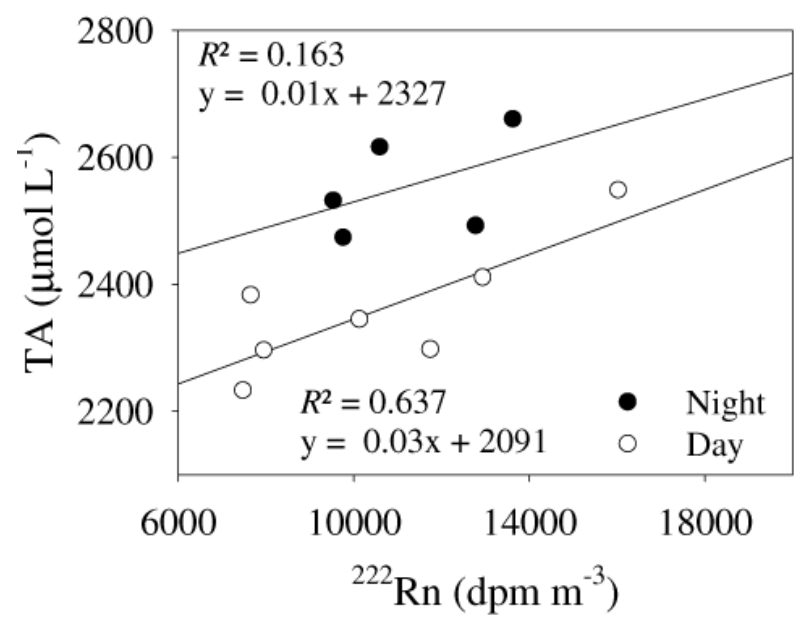

Fig. 10. TA vs. ${ }^{222} \mathrm{Rn}$ concentrations in the water column: separate regressions were made for daytime and nighttime hours. The three daylight time points taken during the second sampling day were removed from the regressions.

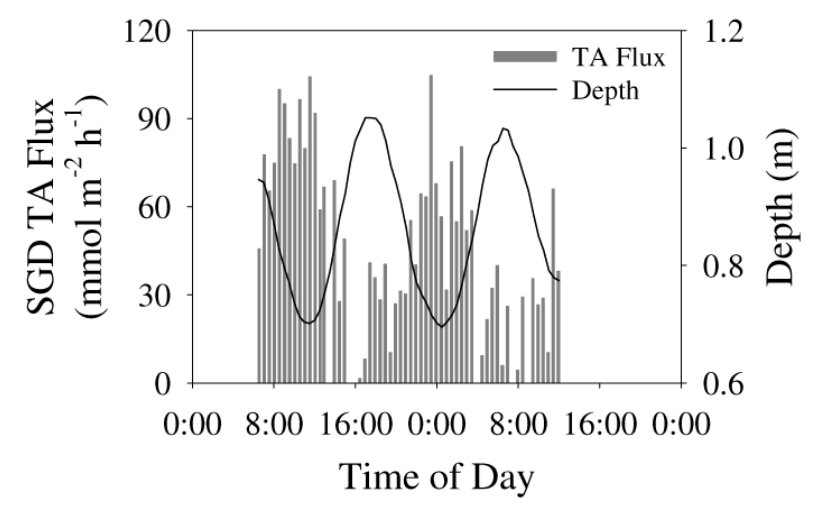

Fig. 11. Hourly SGD-derived flux rates of TA into the water column plotted alongside depth over the course of the study.

Fig. 4) when compared to TA concentrations in other coral reef lagoons ( 2100 to $2400 \mu \mathrm{mol} \mathrm{L}^{-1}$ ) (Shamberger et al., 2011; Shaw et al., 2012; Silverman et al., 2012; Cyronak et al., 2013) and the nearby Pacific Ocean $\left(\sim 2300 \mu \mathrm{mol} \mathrm{L}^{-1}\right)$ (Millero et al., 1998). This lends support to an external source of TA into Muri Lagoon.

There are a number of factors that would influence the flux of TA from SGD into coastal ecosystems, one of which is the concentration of TA in the groundwater. In general TA concentrations of groundwater exhibit a large range and are probably highly dependent on local geology, but can be up to 6 times as high as oceanic TA (Table 3). Also, the amount of TA fluxed into the lagoon is dependent on how far the groundwater mixes offshore and the location of point sources of SGD within the lagoon (Burnett et al., 2003; Burnett and Dulaiova, 2003; Schopka and Derry, 2012). Based on radium isotope ratios in Muri Lagoon, a conservative residence time

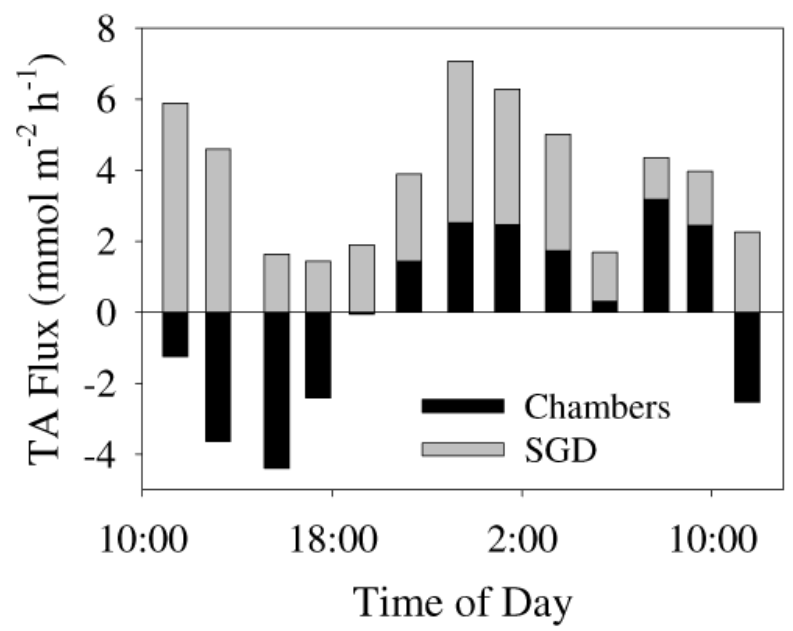

Fig. 12. Hourly flux rates of TA from advective sediment incubations and SGD along a $750 \mathrm{~m}$ transect from the study site to reef crest. $100 \%$ cover was assumed for advective sediments, and SGD was estimated as mixing $50 \mathrm{~m}$ offshore.

of 6 days was estimated for water in the lagoon. This long residence time means TA derived from groundwater can accumulate in the lagoon, raising the water column $\Omega_{\mathrm{Ar}}$ above oceanic levels and potentially buffer against ocean acidification. However, groundwater may also act as a source of $\mathrm{CO}_{2}$, which would inhibit the buffering capacity of SGDderived TA fluxes. Also, groundwater is a potential source of nutrients (Valiela et al., 1999; Burnett et al., 2003; Paytan et al., 2006), contaminants (Cohen et al., 1984; Bedient et al., 1994), and other solutes that could degrade reef health.

There are not many studies assessing the influence of SGD on alkalinity fluxes to the water column, and none in coral reef ecosystems. Moore et al. (2011) used radium isotopes to trace the fluxes of groundwater to the Wadden Sea, showing that SGD acts as an important source of TA, Mn, dissolved organic carbon (DOC), and silicate to the ocean. Other studies have measured the concentration of TA in groundwater, but do not discuss SGD fluxes of TA to open water ecosystems (see Table 3). There are multiple groundwater exchange processes besides terrestrial hydraulic gradients that could alter TA cycling in coral lagoons (Burnett et al., 2003; Santos et al., 2012). For instance, tidal pumping and saltwater intrusion occurring on a larger scale than advective process may alter microbial processes in the sediment, and subsequently the cycling of TA (Kuan et al., 2012; Santos et al., 2012). The impact of these processes on TA fluxes into coral reef lagoons merits further investigation. Also, any seasonal variability in rainfall may influence SGD flux rates over larger temporal and spatial scales. 
Table 3. Concentrations of TA $\left(\mu \mathrm{mol} \mathrm{L}{ }^{-1}\right)$ measured in groundwater throughout the world. ${ }^{*}$ Designates concentrations measured as $\mathrm{HCO}_{3}^{-}$.

\begin{tabular}{llll}
\hline TA $(\mu \mathrm{mol} \mathrm{L}$ & -1 \\
& System type & Location & Reference \\
\hline $2150-2949$ & Subtropical estuary & South Carolina, USA & Cai et al. (2003) \\
$90-8920$ & Subtropical estuary & Kunsan, South Korea & Kim et al. (2004) \\
4020 & Subtropical estuary & Southern China & Liu et al. (2012) \\
$753-7026^{*}$ & Inland mountains & Central Mexico & Mahlknecht et al. (2004) \\
$2550-23300$ & Tidal flat & Wadden Sea, Germany & Moore (2011) \\
$95-2000^{*}$ & Tropical island & Guadeloupe & Rad et al. (2007) \\
$1400-13000^{*}$ & Tropical island & Martinique & Rad et al. (2007) \\
$800-4016^{*}$ & Tropical island & Réunion & Rad et al. (2007) \\
$2290^{*}$ & Coastal lagoon & Brazil & Santos et al. (2008) \\
$1328-2162$ & Tropical island & Hawaiian Islands & Schopka and Derry (2012) \\
$3989-7134$ & Tropical island & Cook Islands & This study \\
\hline
\end{tabular}

\subsection{Upscaling porewater and groundwater fluxes}

Because the flux rates of these benthic processes are variable temporally and spatially, any extrapolation needs to be taken with care. In order to compare the two sources of groundwater and their influence on TA concentrations in the lagoon, a $750 \mathrm{~m} \times 41 \mathrm{~m}$ transect was projected from the sampling site to the reef crest (Fig. 1). The flow of water in the lagoon is generally from the reef crest towards shore; therefore, any changes in the water column chemistry would occur along this transect. Since chamber stirring rates did not show any major influence on hourly TA fluxes from the sediments, an average hourly flux rate from the two advective chambers (40 and 60 RPM) was used for this comparison. Since currents are the main driver of porewater advection, the different stirring rates would likely reflect any variability within the lagoon. SGD was conservatively assumed to occur within a horizontal seepage face of $50 \mathrm{~m}$ from the beach face, as suggested from resistivity transects.

The fluxes of TA associated with advective processes were both negative and positive while the groundwater fluxes were always positive (Fig. 12). Combined TA flux rates from both SGD and porewater advection along the $750 \mathrm{~m}$ transect were between 62.1 and $72.9 \mathrm{mmol} \mathrm{m}^{-2} \mathrm{~d}^{-1}$, which is above the TA uptake rates of coral lagoons ( 26 to $42 \mathrm{mmol} \mathrm{m}^{-2} \mathrm{~d}^{-1}$ ) as measured by Kinsey (1983). These flux rates are consistent with the elevated TA concentrations measured at the sampling site. On a daily basis, porewater advection fluxed from 2.1 to $4.7 \mathrm{mmol}^{\mathrm{TA} \mathrm{m}}{ }^{-2} \mathrm{~d}^{-1}$ into the lagoon, while SGD fluxed 60 to $67 \mathrm{mmol} \mathrm{TA} \mathrm{m}^{-2} \mathrm{~d}^{-1}$ along the $750 \mathrm{~m}$ transect. SGD contributed $27 \%$ to $97 \%$ of the combined groundwater fluxes over a diel cycle, with the percent contribution dependent on both the time of day and the tidal cycle (Fig. 12). Since groundwater seepage is correlated with tidal height (Chanton et al., 2003), larger tides would have more of an effect on groundwater flow, potentially fluxing more TA into the system during those tidal cycles. However, because advective processes follow a diel cycle and groundwa- ter is driven by tidal cycles, longer term experiments may be needed to reveal which of the processes is more influential.

Previous studies have estimated coral reef community calcification rates that range from 31.2 to $292.8 \mathrm{mmol}$ $\mathrm{CaCO}_{3} \mathrm{~m}^{-2} \mathrm{~d}^{-1}$ (or -62.4 to $-585.6 \mathrm{mmol} \mathrm{TA} \mathrm{m}^{-2} \mathrm{~d}^{-1}$ ) (Shamberger et al., 2011). Using that range of community TA uptake rates along the $750 \mathrm{~m}$ transect reveals that porewater advection can add from 0.4 to $7.5 \%$ of the TA taken out of the water column by coral communities. SGD-derived TA fluxes can add from $10 \%$ to $107 \%$ of the TA taken up by coral communities. The community TA uptake rates of coral lagoons are generally low compared to other reef ecosystems (Kinsey, 1983), which means it is likely that groundwater processes contribute towards the higher end of that range in Muri Lagoon. This is consistent with the elevated TA concentrations at the study site. This previously unaccounted for source of TA is important in changing the carbonate chemistry within Muri Lagoon over tidal and diel cycles.

\section{Conclusions}

Alkalinity concentrations in Muri Lagoon followed a pattern that is indicative of both biological and tidal drivers influencing the dynamics of water column TA over a diel cycle (Fig. 4). Different groundwater exchange mechanisms, acting on varying temporal and spatial scales, can have different influences on water column alkalinity. Small-scale porewater advection acted as both a source and sink of TA over the course of a day, with net daily fluxes ranging from -1.55 to $7.76 \mathrm{mmol} \mathrm{m}^{-2} \mathrm{~d}^{-1}$ depending on advection rates. Based on the average of the 40 and 60 RPM chambers along the $750 \mathrm{~m}$ transect, porewater advection was a net source of TA to the lagoon (2.1 to $\left.4.7 \mathrm{mmol} \mathrm{m}^{-2} \mathrm{~d}^{-1}\right)$. SGD fluxes were driven by tidal processes and delivered $1080 \mathrm{mmol} \mathrm{TA} \mathrm{m}^{-2} \mathrm{~d}^{-1}$ to the water column at the study site. The daily SGD-derived TA flux is high when compared to other sources and sinks of TA. However, it is site-specific and groundwater is likely discharged only a discrete distance from shore. Along the 
$750 \mathrm{~m}$ transect, SGD fluxed from 60 to $67 \mathrm{mmol} \mathrm{TA} \mathrm{m}^{-2}$ $\mathrm{d}^{-1}$ to the water column. It is likely that similar advective exchanges of TA occur throughout different reef systems, while SGD is highly dependent on the specific geological, physical, and biological attributes of the land masses associated with coral reefs. It is important to constrain the variability of SGD-derived fluxes over larger temporal and spatial scales by measuring ${ }^{222} \mathrm{Rn}$ concentrations across broad areas of coral reef environments. Assessing groundwater exchange processes occurring in coral reef ecosystems is necessary so that more detailed models predicting how ocean acidification will alter reef carbonate chemistry can be developed.

Acknowledgements. Kevin Befus, Alicia Hidden, and Douglas Tait provided valuable help during the field campaign. Matheus Carvalho skilfully ran DIC isotope samples, and Iain Alexander ran nutrient samples. This project was funded by the Australian Research Council grants (LP100200732 and DP110103638), the Australian Agency for International Development (AusAID), and the Cook Islands Ministry of Infrastructure and Planning.

Edited by: S. Bouillon

\section{References}

Andersson, A. J. and Gledhill, D.: Ocean acidification and coral reefs: Effects on breakdown, dissolution, and net ecosystem calcification, An. Rev. Mar. Sci., 5, 321-348, doi:10.1146/annurevmarine-121211-172241, 2013.

Andersson, A. J. and Mackenzie, F. T.: Revisiting four scientific debates in ocean acidification research, Biogeosciences, 9, 893905, doi:10.5194/bg-9-893-2012, 2012.

Andersson, A., Bates, N., and Mackenzie, F.: Dissolution of carbonate sediments under rising $p \mathrm{CO}_{2}$ and ccean acidification: Observations from Devil's Hole, Bermuda, Aq. Geochem., 13, 237264, doi:10.1007/s10498-007-9018-8, 2007.

Bedient, P. B., Rifai, H. S., and Newell, C. J.: Ground water contamination: transport and remediation, Prentice-Hall International, Inc., USA, 1994.

Blanco, A. C., Watanabe, A., Nadaoka, K., Motooka, S., Herrera, E. C., and Yamamoto, T.: Estimation of nearshore groundwater discharge and its potential effects on a fringing coral reef, Mar. Pollut. Bull., 62, 770-785, 2011.

Burnett, W. C. and Dulaiova, H.: Estimating the dynamics of groundwater input into the coastal zone via continuous radon222 measurements, J. Environ. Radioact., 69, 21-35, 2003.

Burnett, W., Kim, G., and Lane-Smith, D.: A continuous monitor for assessment of 222Rn in the costal ocean, J. Radioanalyt. Nuc. Chem., 249, 167-172, 2001.

Burnett, W. C., Bokuniewicz, H., Huettel, M., Moore, W. S., and Taniguchi, M.: Groundwater and pore water inputs to the coastal zone, Biogeochemistry, 66, 3-33, doi:10.1023/b:biog.0000006066.21240.53, 2003.

Burnett, W., Aggarwal, P., Aureli, A., Bokuniewicz, H., Cable, J., Charette, M., Kontar, E., Krupa, S., Kulkarni, K., and Loveless, A.: Quantifying submarine groundwater discharge in the coastal zone via multiple methods, Sci. Total Environ., 367, 498-543, 2006.

Cable, J., Burnett, W., Chanton, J., and Weatherly, G.: Modeling groundwater flow into the ocean based on ${ }^{222} \mathrm{Rn}$, Earth Planet. Sci. Lett, 144, 591-604, 1996.

Cai, W. J., Wang, Y., Krest, J., and Moore, W.: The geochemistry of dissolved inorganic carbon in a surficial groundwater aquifer in North Inlet, South Carolina, and the carbon fluxes to the coastal ocean, Geochim. Cosmochim. Acta, 67, 631-639, 2003.

Chanton, J. P., Burnett, W. C., Dulaiova, H., Corbett, D. R., and Taniguchi, M.: Seepage rate variability in Florida Bay driven by Atlantic tidal height, Biogeochemistry, 66, 187-202, 2003.

Chisholm, J. R. M. and Gattuso, J.-P.: Validation of the alkalinity anomaly technique for investigating calcification and photosynthesis in coral reef communities, Limnol. Oceanogr., 36, 12321239, 1991.

Cohen, S., Creeger, S., Carsel, R., and Enfield, C.: Potential pesticide contamination of groundwater from agricultural uses, ACS Symposium Series, 297-325, 1984.

Cook, P.L. M. and Røy, H.: Advective relief of $\mathrm{CO}_{2}$ limitation in microphytobenthos in highly productive sandy sediments, Limnol. Oceanogr., 51, 1594-1601, 2006.

Cyronak, T., Santos, I., McMahon, A., and Eyre, B. D.: Carbon cycling hysteresis in permeable carbonate sands over a diel cycle: Implications for ocean acidification, Limnol. Oceanogr., 58, 131-143, doi:10.4319/1o.2013.58.1.0131, 2013.

D'Elia, C. F. and Wiebe, W. J.: Biogeochemical nutrient cycles in coral-reef ecosystems, Ecosystems of the world, 25, 49-74, 1990.

De'ath, G., Lough, J. M., and Fabricius, K. E.: Declining Coral Calcification on the Great Barrier Reef, Science, 323, 116-119, doi:10.1126/science.1165283, 2009.

Dickson, A. and Millero, F.: A comparison of the equilibrium constants for the dissociation of carbonic acid in seawater media, Deep-Sea Res. Pt. A, 34, 1733-1743, 1987.

Doney, S. C., Fabry, V. J., Feely, R. A., and Kleypas, J. A.: Ocean acidification: the other $\mathrm{CO}_{2}$ problem, Mar. Sci., 1, 169-192, 2009.

Dulaiova, H., Gonneea, M. E., Henderson, P. B., and Charette, M. A.: Geochemical and physical sources of radon variation in a subterranean estuary - implications for groundwater radon activities in submarine groundwater discharge studies, Mar. Chem., 110, 120-127, 2008.

Eadie, B. J. and Jeffrey, L. M.: ${ }^{13} \mathrm{C}$ analyses of oceanic particulate organic matter, Mar. Chem., 1, 199-209, 1973.

Eyre, B. D. and Ferguson, A. J. P.: Benthic metabolism and nitrogen cycling in a subtropical east Australian estuary(Brunswick): Temporal variability and controlling factors, Limnol. Oceanogr., 50, 81-96, 2005.

Eyre, B. D., Glud, R. N., and Patten, N.: Mass coral spawning: A natural large-scale nutrient addition experiment, Limnol. Oceanogr., 53, 997-1013, 2008.

Fabry, V. J., Seibel, B. A., Feely, R. A., and Orr, J. C.: Impacts of ocean acidification on marine fauna and ecosystem processes, ICES J. Mar. Sci., 65, 414-432, 2008.

Feely, R. A., Sabine, C.L., Lee, K., Berelson, W., Kleypas, J., Fabry, V. J., and Millero, F. J.: Impact of anthropogenic $\mathrm{CO}_{2}$ on the $\mathrm{CaCO}_{3}$ system in the oceans, Science, 305, 362-366, doi:10.1126/science.1097329, 2004. 
Frankignoulle, M., Gattuso, J. P., Biondo, R., Bourge, I., CopinMontégut, G., and Pichon, M.: Carbon fluxes in coral reefs, II. Eulerian study of inorganic carbon dynamics and measurement of air-sea CO2 exchanges, Mar. Ecol. Prog. Ser., 145, 123-132, doi:10.3354/meps 145123, 1996.

Gattuso, J., Pichon, M., Delesalle, B., Canon, C., and Frankignoulle, M.: Carbon fluxes in coral reefs, I. Lagrangian measurement of community metabolism and resulting air-sea $\mathrm{CO}_{2}$ disequilibrium, MEPS, 145, 109-121, 1996.

Gattuso, J. P., Frankignoulle, M., Bourge, I., Romaine, S., and Buddemeier, R. W.: Effect of calcium carbonate saturation of seawater on coral calcification, Global Planet. Change, 18, 37-46, doi:10.1016/s0921-8181(98)00035-6, 1998.

Glud, R. N., Eyre, B. D., and Patten, N.: Biogeochemical responses to mass coral spawning at the Great Barrier Reef: Effects on respiration and primary production, Limnol. Oceanogr., 53, 10141024, 2008.

Gray, S. E. C., DeGrandpre, M. D., Langdon, C., and Corredor, J. E.: Short-term and seasonal $\mathrm{pH}, p \mathrm{CO}_{2}$ and saturation state variability in a coral-reef ecosystem, Global Biogeochem. Cy., 26, GB3012, doi:10.1029/2011gb004114, 2012.

Holden, B. J.: Circulation and flushing Ngatangiia harbour and Muri lagoon Rarotonga, Cook Islands, South Pacific Applied Geoscience Commission, 1992.

$\mathrm{Hu}, \mathrm{X}$. and Burdige, D. J.: Enriched stable carbon isotopes in the pore waters of carbonate sediments dominated by seagrasses: Evidence for coupled carbonate dissolution and reprecipitation, Geochim. Cosmochim. Acta, 71, 129-144, 2007.

Kim, K., Rajmohan, N., Kim, H. J., Hwang, G. S., and Cho, M. J.: Assessment of groundwater chemistry in a coastal region (Kunsan, Korea) having complex contaminant sources: a stoichiometric approach, Environ. Geol., 46, 763-774, 2004.

Kinsey, D. W.: Standards of performance in coral reef primary production and carbon turnover, Perspectives on coral reefs. Brian Clouston Publisher, Manuka, Australia, 209-220, 1983.

Kleypas, J. A. and Langdon, C.: Coral Reefs and Changing Seawater Carbonate Chemistry, Coast. Estuarine Studies, 61, 73-110, doi:10.1029/61CE06, 2006.

Knee, K.L., Street, J. H., Grossman, E. E., Boehm, A. B., and Paytan, A.: Nutrient inputs to the coastal ocean from submarine groundwater discharge in a groundwater-dominated system: Relation to land use (Kona coast, Hawai'i, USA), Limnol. Oceanogr., 55, 1105-1122, 2010.

Köhler, P., Fischer, H., Schmitt, J., and Munhoven, G.: On the application and interpretation of Keeling plots in paleo climate research - deciphering ${ }^{13} \mathrm{C}$ of atmospheric $\mathrm{CO}_{2}$ measured in ice cores, Biogeosciences, 3, 539-556, doi:10.5194/bg-3-539-2006, 2006.

Ku, T. C. W., Walter, L. M., Coleman, M.L., Blake, R. E., and Martini, A. M.: Coupling between sulfur recycling and syndepositional carbonate dissolution: evidence from oxygen and sulfur isotope composition of pore water sulfate, South Florida Platform, U.S.A, Geochim. Cosmochim. Acta, 63, 2529-2546, doi:10.1016/s0016-7037(99)00115-5, 1999.

Kuan, W. K., Jin, G., Xin, P., Robinson, C., Gibbes, B., and Li,L.: Tidal influence on seawater intrusion in unconfined coastal aquifers, Water Resour. Res., 48, W02502, doi:10.1029/2011wr010678, 2012.
Lazar, B. and Loya, Y.: Bioerosion of coral reefs-A chemical approach, Limnol. Oceanogr., 36, 377-383, 1991.

Levy, O., Dubinsky, Z., Schneider, K., Achituv, Y., Zakai, D., and Gorbunov, M. Y.: Diurnal hysteresis in coral photosynthesis, Mar. Ecol. Prog. Ser., 268, 105-117, 2004.

Lewis, J. B.: Measurements of groundwater seepage flux onto a coral reef: Spatial and temporal variations, Limnol. Oceanogr., 1165-1169, 1987.

Liu, Q., Dai, M., Chen, W., Huh, C.-A., Wang, G., Li, Q., and Charette, M. A.: How significant is submarine groundwater discharge and its associated dissolved inorganic carbon in a river-dominated shelf system?, Biogeosciences, 9, 1777-1795, doi:10.5194/bg-9-1777-2012, 2012.

Mahlknecht, J., Steinich, B., and Navarro de León, I.: Groundwater chemistry and mass transfers in the Independence aquifer, central Mexico, by using multivariate statistics and mass-balance models, Environ. Geol., 45, 781-795, 10.1007/s00254-003-0938-3, 2004.

Manzello, D. P., Kleypas, J. A., Budd, D. A., Eakin, C. M., Glynn, P. W., and Langdon, C.: Poorly cemented coral reefs of the eastern tropical Pacific: Possible insights into reef development in a high- $\mathrm{CO}_{2}$ world, Proc. of the Natl. Ac. Sc., 105, 10450-10455, doi:10.1073/pnas.0712167105, 2008.

Mehrbach, C., Culberson, C., Hawley, J., and Pytkowicz, R.: Measurement of the apparent dissociation constants of carbonic acid in seawater at atmospheric pressure, Limnol. Oceanogr., 897907, 1973.

Millero, F. J.: The thermodynamics of the carbonate system in seawater, Geochim. Cosmochim. Acta, 43, 1651-1661, doi:10.1016/0016-7037(79)90184-4, 1979.

Millero, F. J., Lee, K., and Roche, M.: Distribution of alkalinity in the surface waters of the major oceans, Mar. Chem., 60, 111-130, 1998.

Moore, W., Beck, M., Riedel, T., Rutgers van der Loeff, M., Dellwig, O., Shaw, T., Schnetger, B., and Brumsack, H. J.: Radiumbased pore water fluxes of silica, alkalinity, manganese, DOC, and uranium: A decade of studies in the German Wadden Sea, Geochim. Cosmochim. Acta, 75, 6535-6555, 2011.

Morse, J. W., Andersson, A. J., and Mackenzie, F. T.: Initial responses of carbonate-rich shelf sediments to rising atmospheric pCO2 and "ocean acidification": Role of high Mg-calcites, Geochim. Cosmochim. Acta, 70, 5814-5830, doi:10.1016/j.gca.2006.08.017, 2006.

Mortazavi, B. and Chanton, J. P.: Use of Keeling plots to determine sources of dissolved organic carbon in nearshore and open ocean systems, Limnol. Oceanogr., 49, 102-108, 2004.

Oakes, J. M., Eyre, B. D., Ross, D. J., and Turner, S. D.: Stable Isotopes Trace Estuarine Transformations of Carbon and Nitrogen from Primary- and Secondary-Treated Paper and Pulp Mill Effluent, Environ. Sci. Technol., 44, 7411-7417, doi:10.1021/es101789v, 2010.

Ogrinc, N., Faganeli, J., and Pezdic, J.: Determination of organic carbon remineralization in near-shore marine sediments (Gulf of Trieste, Northern Adriatic) using stable carbon isotopes, Org. Geochem., 34, 681-692, 2003.

Orr, J. C., Fabry, V. J., Aumont, O., Bopp, L., Doney, S. C., Feely, R. A., Gnanadesikan, A., Gruber, N., Ishida, A., and Joos, F.: Anthropogenic ocean acidification over the twenty-first century and its impact on calcifying organisms, Nature, 437, 681-686, 
2005.

Paytan, A., Shellenbarger, G. G., Street, J. H., Gonneea, M. E., Davis, K., Young, M. B., and Moore, W. S.: Submarine groundwater discharge: An important source of new inorganic nitrogen to coral reef ecosystems, Limnol. Oceanogr., 51, 343-348, 2006.

Pierrot, D., Lewis, E., and Wallace, D. W. R.: MS Excel program developed for $\mathrm{CO}_{2}$ system calculations (Version ORNL/CDIAC105a), Oak Ridge, TN: Carbon Dioxide Information Analysis Center, Oak Ridge National Laboratory, 2006.

Precht, E. and Huettel, M.: Advective Pore-Water Exchange Driven by Surface Gravity Waves and Its Ecological Implications, Limnol. Oceanogr., 48, 1674-1684, 2003.

Rad, S. D., Allègre, C. J., and Louvat, P.: Hidden erosion on volcanic islands, Earth Planet. Sci. Lett., 262, 109-124, 2007.

Rao, A. M. F., Polerecky, L., Ionescu, D., Meysman, F. J. R., and de Beer, D.: The influence of pore-water advection, benthic photosynthesis, and respiration on calcium carbonate dynamics in reef sands, Limnol. Oceanogr., 57, 809-825, 2012.

Sabine, C. L., Feely, R. A., Gruber, N., Key, R. M., Lee, K., Bullister, J. L., Wanninkhof, R., Wong, C. S., Wallace, D. W. R., Tilbrook, B., Millero, F. J., Peng, T.-H., Kozyr, A., Ono, T., and Rios, A. F.: The Oceanic Sink for Anthropogenic $\mathrm{CO}_{2}$, Science, 305, 367-371, doi:10.1126/science.1097403, 2004.

Santos, I. R., Machado, M. I., Niencheski, L. F., Burnett, W., Milani, I. B., Andrade, C. F. F., Peterson, R. N., Chanton, J., and Baisch, P.: Major ion chemistry in a freshwater coastal lagoon from southern Brazil (Mangueira Lagoon): Influence of groundwater inputs, Aqu. Geochem., 14, 133-146, 2008.

Santos, I. R., Dimova, N., Peterson, R. N., Mwashote, B., Chanton, J., and Burnett, W. C.: Extended time series measurements of submarine groundwater discharge tracers $\left({ }^{222} \mathrm{Rn}\right.$ and $\left.\mathrm{CH}_{4}\right)$ at a coastal site in Florida, Mar. Chem., 113, 137-147, 2009.

Santos, I. R., Glud, R. N., Maher, D., Erler, D., and Eyre, B. D.: Diel coral reef acidification driven by porewater advection in permeable carbonate sands, Heron Island, Great Barrier Reef, Geophys. Res. Lett., 38, L03604, doi:10.1029/2010g1046053, 2011.

Santos, I. R., Eyre, B. D., and Huettel, M.: The driving forces of porewater and groundwater flow in permeable coastal sediments: A review, Estuar. Coast. Shelf Sci., 98, 1-15, doi:10.1016/j.ecss.2011.10.024, 2012.

Schneider, K., Levy, O., Dubinsky, Z., and Erez, J.: In situ diel cycles of photosynthesis and calcification in hermatypic corals, Limnol. Oceanogr., 54, 1995-2002, 2009.

Schopka, H. H. and Derry, L. A.: Chemical weathering fluxes from volcanic islands and the importance of groundwater: The Hawaiian example, Earth Planet. Sci. Lett., 339, 67-78, 2012.
Shamberger, K. E. F., Feely, R. A., Sabine, C.L., Atkinson, M. J., DeCarlo, E. H., Mackenzie, F. T., Drupp, P. S., and Butterfield, D. A.: Calcification and organic production on a Hawaiian coral reef, Mar. Chem., 127, 64-75, doi:10.1016/j.marchem.2011.08.003, 2011.

Shaw, E. C., McNeil, B. I., and Tilbrook, B.: Impacts of ocean acidification in naturally variable coral reef flat ecosystems, J. Geophys. Res., 117, C03038, doi:10.1029/2011jc007655, 2012.

Silverman, J., Kline, D. I., Johnson, L., Rivlin, T., Schneider, K., Erez, J., Lazar, B., and Caldeira, K.: Carbon turnover rates in the One Tree Island reef: A 40-year perspective, J. Geophys. Res., 117, G03023, doi:10.1029/2012jg001974, 2012.

Suzuki, A., and Kawahata, H.: Carbon budget of coral reef systems: an overview of observations in fringing reefs, barrier reefs and atolls in the Indo-Pacific regions, Tellus B, 55, 428-444, 2003.

Thompson, C. S.: The climate and weather of the southern Cook Islands, New Zealand Meteorological Service, 1986.

Valiela, I., Costa, J., Foreman, K., Teal, J. M., Howes, B., and Aubrey, D.: Transport of groundwater-borne nutrients from watersheds and their effects on coastal waters, Biodegradation, 10, 177-197, 1999.

Waterhouse, B., Petty, D. R., and Mackenzie, I.: Hydrogeology of the Southern Cook Islands, South Pacific, 98, Published for New Zealand Geological Survey by Science Information Publication Centre, 1986.

Weber, J. N. and Woodhead, P. M. J.: Factors affecting the carbon and oxygen isotopic composition of marine carbonate sediments, II. Heron Island, Great Barrier Reef, Australia, Geochim. Cosmochim. Acta, 33, 19-38, doi:10.1016/0016-7037(69)90090-8, 1969.

Williams, B., Halfar, J., Steneck, R. S., Wortmann, U. G., Hetzinger, S., Adey, W., Lebednik, P., and Joachimski, M.: Twentieth century $\delta^{13} \mathrm{C}$ variability in surface water dissolved inorganic carbon recorded by coralline algae in the northern North Pacific Ocean and the Bering Sea, Biogeosciences, 8, 165-174, doi:10.5194/bg-8-165-2011, 2011.

Wolf-Gladrow, D. A., Zeebe, R. E., Klaas, C., Körtzinger, A., and Dickson, A. G.: Total alkalinity: The explicit conservative expression and its application to biogeochemical processes, Mar. Chem., 106, 287-300, 2007.

Zeebe, R. E. and Wolf-Gladrow, D.: $\mathrm{CO}_{2}$ in seawater: Equilibrium, kinetics, isotopes., Elsevier Oceanography Series, Amsterdam, p. 65, 2001.

Zundelevich, A., Lazar, B., and Ilan, M.: Chemical versus mechanical bioerosion of coral reefs by boring sponges-lessons from $\mathrm{Pi}$ one cf. vastifica, J. Exp. Biol., 210, 91-96, 2007. 